\title{
ALI LAHKO PROCES PROFESIONALNEGA VOJAŠKEGA IZOBRAŽEVANJA USTVARI VOJAŠKE STRATEGE?
}

Povzetek Novembra 2011 je na Poveljstvu za doktrino, razvoj, izobraževanje in usposabljanje potekalo 5. redno srečanje Foruma centralnih evropskih držav o vojaškem izobraževanju (Central European Forum on Military Education - CEFME). Osrednja tema posveta je bila izobraževanje vojaških strategov. Na srečanju so sodelovali visoki predstavniki s področja vojaškega izobraževanja iz devetih srednjeevropskih držav in predstavnik zveze Nato. Osrednja referata sta pripravila Uroš Krek, predavatelj predmeta vojaška strategija v generalštabnem programu Slovenske vojske, in polkovnica Mojca Pešec. V nadaljevanju avtorja predstavljata poglede na programe izobraževanja vojaških strategov v Sloveniji s teoretičnega in praktičnega vidika in utemeljujeta potrebo po intenzivnejšem in kakovostnejšem študiju strateške teorije za učitelje in študente predmeta vojaška strategija, nujnost oblikovanja celovitega programa učenja strategije z vidika izbora udeležencev in predavateljev ter potrebo po postavljanju dosegljivih ciljev, ko gre za časovni obseg in določanje vsebin programa.

Ključne besede

Abstract In November 2011, the 5th regular meeting of the Central European Forum on Military Education (CEFME) was convened at the Doctrine, Development, Education and Training Command. The central theme of the conference was military strategist training. The meeting brought together senior military education representatives from nine Central European countries, and a representative of NATO. The two central papers were prepared by Uroš Krek, military strategy lecturer in the Slovenian Armed Forces General Staff Programme, and by Colonel Mojca Pešec. In their article, the authors present views on education programmes for military strategists in Slovenia from the theoretical and practical point of view, and substantiate the need for more intensive and better quality 
strategic theory study programmes for military strategy teachers and students. They also define the need for developing a comprehensive programme of learning the strategy in terms of selection of participants and lecturers, and the need for setting up achievable targets when it comes to time frame and the determination of programme subjects.

Key words Strategy, military strategist, military education and training.

Uvod V zadnjem desetletju se države spoprijemajo z vedno hujšimi grožnjami svetovni varnosti. Grožnje so, v primerjavi s tistimi iz prejšnjih obdobij, intenzivnejše, bolj kompleksne, večdimenzionalne in predvsem nepredvidljive. Zmanjšuje se pomen klasičnih vojaških groženj, vse pogostejše pa so nevojaške grožnje varnosti. Kljub stalnim prizadevanjem svetovne skupnosti za vzpostavljanje miru in varnosti, postaja obvladovanje groženj vedno zahtevnejše. Države, pa tudi mednarodne institucije, kot je Nato, si prizadevajo, da bi vzpostavile sistemske rešitve in ustrezne mehanizme za zagotavljanje usklajenega in celovitega pristopa (Comprehensive Approach) za reševanje sodobnih kriz in pri tem med seboj povezale več (pristojnih) institucij. Da bi bolje obvladovali morebitne krizne razmere, zato na ravni posameznih držav in na mednarodni ravni nastajajo sistemi kriznega upravljanja, ki določajo koordinacijo, medagencijsko sodelovanje in mobilizacijo družbenih virov ipd.

Toda kakšni naj bodo vojaški ali civilni strokovnjaki, voditelji, ki bodo sposobni usmerjati in voditi take kompleksne sisteme? Kakšno znanje in sposobnosti morajo imeti, da bodo zmogli učinkovito združevati strokovna dognanja in izsledke zelo specializiranih vladnih in nevladnih agencij v ustrezne protikrizne ukrepe?

Za spoprijemanje $\mathrm{z}$ varnostnimi tveganji in grožnjami današnjega časa in v prihodnosti je pomembno imeti prave ljudi na pravih mestih ter $\mathrm{v}$ pravem trenutku. Vsaka država bi morala oblikovati in vzpostaviti sistem odkrivanja, izbire, izobraževanja in usposablja kandidatov za voditelje, ki bodo sposobni strateškega vodenja in odločanja o zadevah nacionalne varnosti. Voditeljstvo pomeni spoprijemanje z izzivi, zmožnost motiviranja, združevanja in usmerjanja ljudi k določenim ciljem. Država, ki želi oblikovati učinkovito vladno strategijo za odpravljanje groženj varnosti, mora imeti sposobne voditelje na vsaki ravni upravljanja, voditelje, ki z znanjem, veščinami in osebnostnimi lastnostmi uspešno vodijo in upravljajo celovite sisteme in organizacije.

\section{ALI JE VOJAŠKEGA STRATEGA MOGOČE OBLIKOVATI Z USTREZNIMI IZOBRAŽEVANJEM}

Narava pojma strategija vsebuje poleg sposobnosti za načrtovanje še ciljno naravnanost in sposobnost predvidevanja učinkovitih dejavnosti za dosego političnih in vojaških ciljev. Predvideva poseben način razmišljanja in ravnanja, zmožnost 
širšega vpogleda v okoliščine ter razumevanje zvez in odvisnosti med aktivnostmi in posledicami. Narava strategije je univerzalna, ni vezana le na določen prostor in čas. Študente strategije je zato treba naučiti strateškega razmišljanja zunaj znanih okvirov. Učitelji strategije ne ustvarjajo strokovnjakov, ki bodo reševali strateške zadeve zgodnjega 21. stoletja, temveč izobražujejo stratege, sposobne strateškega razmišljanja in strateške presoje $\mathrm{v}$ vseh časovnih in prostorskih situacijah.

Strateg mora znati dolgoročno in celovito načrtovati, odločati, poveljevati in voditi, kar je precej odvisno od značaja in osebnostnih lastnosti posameznika (Troha, 2009, str. 77). Ta pa mora razumeti tudi teorijo in znati teoretično znanje nadgraditi z izkušnjami. Zato so pri poučevanju strategije $\mathrm{v}$ formalnem izobraževalnem procesu tudi določene meje; torej tisti, ki najbolje razumejo vojaške teoretike, niso nujno najboljši strategi.

Strateških genijev je malo, posamezniki s strateškim talentom pa so tako v vojskah kot v poslovnem svetu. Kot vsak talent se tudi strateški da izboljšati z izobraževanjem in delovanjem v ustreznih okoliščinah. Združevanje osebnostnih lastnosti in vrednot z znanjem in veščinami v procesu izobraževanja ter usposabljanja dopolnjuje in razvija zmožnosti posameznikov (Troha, 2009, str. 74).

Vsi profesionalni vojaški izobraževalni sistemi verjamejo, da izobražujejo vojaške stratege in voditelje. Kurikulumi na visokih vojaških izobraževanjih pa pogosto niso ciljno usmerjeni v razvijanje in spodbujanje strateškega in kritičnega mišljenja. Bolj jih oblikujejo značilnosti in pričakovanja udeležencev izobraževanja, ki so se v izobraževanje vključili zato, ker so opravljali dolžnosti, ki so jim omogočile napredovanje in nadaljnje izobraževanje. Izbor udeležencev strateških izobraževanj ni opravljen na podlagi znanstvenih postopkov oziroma metod, ki bi ugotavljali njihove psihofizične in značajske lastnosti, temveč so jih kot primerne za ta študij izbrali njihovi nadrejeni (Kotnik, 2008, str. 88-89). Običajno so izbrani zaradi svojih uspehov in prizadevnosti pri opravljanju dolžnosti in ni nujno, da imajo sposobnosti za stratega ali da dosegajo objektivna merila za akademski študij (Baraka et al. 2010; Allen, 2010). Po drugi strani pa se dogaja, da sposobne pripadnike vojske ne pošljejo na šolanje, predvsem tam, kjer prevladuje miselnost, da bi jih tako prikrajšali za izkušnje, ki si jih pridobivajo v praksi. Vemo pa, da taktične izkušnje brez možnosti vpogleda in razumevanja vseh razsežnosti zapletenih situacij ne omogočajo razvoja strategov (Allen, 2010; Bethel et al., 2010).

Strokovnjaki, ki sodelujejo v vojaškem izobraževanju, ugotavljajo, da diplomanti aktualnih univerzitetnih programov ne dosegajo standardov, ki predvidevajo sposobnost oblikovanja koherentnih, logičnih argumentov in pisnega izražanja (Gray, 2009). Sposobnost jasnega izražanja in argumentiranja je zahteva za vstop v profesionalni vojaški izobraževalni sistem. Če tega ni, je treba nalogo razvijati in jo vnesti v kurikulum, kar za načrtovalce vojaškega izobraževanja pomeni izziv. Šolanje v vojaškem izobraževalnem sistemu je zato, žal, še vedno predvsem »nujno zlo«, ki omogoča nadaljnjo kariero, manj pa pomeni čast in priložnost, ki so je deležni 
le izbranci, od katerih se pričakuje, da bodo svoje študijske obveznosti opravili z visoko stopnjo akademske zrelosti. ${ }^{1}$

Vojaški voditelji 21. stoletja se morajo učiti strategije. Študij strategije je nujen na magistrski in doktorski ravni. Kandidati za ta študij morajo biti izbrani na podlagi ocene sposobnosti za učinkovito in smiselno povezovanje vseh vrst in tipov informacij $\mathrm{v}$ koherentne zaključke, ki se lahko uporabijo pri reševanju problemov. Nedvomno je osebna izkušnja najboljši učitelj, enako pomembna in vredna pa sta tudi znanje in modrost, ki izhajata iz del največjih strateških mislecev.

Učenje strategije ne more temeljiti samo na sodobnih izzivih in izzivih, ki jih predvidevamo v bližnji prihodnosti. Strateške študije bi s takim pristopom postale le ozko preučevanje trenutnih razmer. Študenti bi visoko vrednotili le strateške probleme, ki jih ocenjujejo kot zelo pomembne, kar pa bi njihovo razmišljanje omejilo in $\mathrm{s}$ predsodki obremenilo njihovo analizo. Dober strateg je visoko izobražen tudi na drugih področjih, ima veliko splošnega znanja in pozna razvojne zakonitosti družbe, v kateri deluje. Velikokrat je uspešnost strateškega delovanja odvisna tudi od sposobnosti strategov, da vojaške zadeve učinkovito predstavijo v komunikaciji s profesionalnimi politiki (Kotnik, 2008).

\section{TEORETIČNI POGLED NA POMEN IZOBRAŽEVANJA VOJAŠKIH STRATEGOV}

"Nepismeni v 21. stoletju ne bodo tisti, ki ne znajo pisati in brati, pač pa tisti, ki se ne znajo učiti, ki ne znajo pozabiti, kar so se naučili v preteklosti in se določene stvari naučiti na novo."

\section{Alvin Toffler}

Izobraževanje v strategiji je pomembno za razvoj strateškega pristopa, načina razmišljanja, ki lahko reši sodobne in prihodnje strateške izzive. Vendar mora takšno izobraževanje temeljiti na zelo jasnih domnevah o naravi, pomenu in funkciji ter o tem, da se narava strategije nenehno spreminja.

Teoretiki (Gray, Hughes, Lyman, McCausland) se strinjajo, da je dober strateg rezultat narave, osebnosti, torej psiholoških lastnosti in izkušenj, ki so povezane s priložnostmi, ki so bile posamezniku dane v njegovem osebnem in profesionalnem razvoju. Strinjajo se, da je pomembna tudi formalna izobrazba, čeprav ni znanstvenih dokazov, da izobraževanje in usposabljanje res prispevata $\mathrm{k}$ temu, da posameznik postane strateg.

Colin Gray je prepričan, da je danes strateški talent dovolj za delo na strateški ravni. Strateški genij je izjemna redkost, to ni kontinuiran pojav, saj na strateške genije

\footnotetext{
V okviru Strateškega pregleda obrambnega resorja (SPOR 09) iz vojaškega izobraževanja in usposabljanja je bila izvedena raziskava med izvajalci, udeleženci in diplomanti vseh stopenj vojaških izobraževalnih programov v SV,

ki potrujejo navedbe. Ugotovitve raziskave so dostopne v skupnem gradivu opravljenega pregleda na MO RS.
} 
naletimo le občasno. Treba je opredeliti konceptualni temelj, ki bo podlaga za poučevanje strategije in želeno vsebino strateškega izobraževanja. Opozarja tudi, da različne okoliščine zahtevajo različno strateško ravnanje, kar je pri oblikovanju kurikuluma strateškega izobraževanja treba upoštevati (Gray, 2009).

Teorija in praksa strategije morata biti del izobraževanja vojaških strategov. To mora vsebovati ideje in način uresničevanja teh idej v načrtih, ki jih izvajajo poveljniki.

Wayne P. Hughes priporoča, da je treba strategijo in taktiko poučevati tako, da se vsebine dopolnjujejo in nadgrajujejo, ter upoštevati, da je taktika tista, ki določa meje strategiji. Teorija (strategija kot načrt) in praksa (taktična aktivnost) sestavljata celoto. Razlika je med namenom in instrumentom, s katerim se namen dosega. Zato je treba teorijo in prakso strategije poučevati na vsaki ravni vojskovanja in za vsako vojno oziroma oboroženi spopad (Hughes, 1989, str. 75).

Robert Lyman je prepričan, da morajo operativno raven vojskovanja voditi generali, ki imajo strateški občutek (Lyman, 2008). Vendar pa obstaja tradicionalno prepričanje, da je operativna raven vojskovanja tista, na kateri se izvaja le vodenje $\mathrm{v}$ vojaškem smislu, ki nima prvin politike (Gray, 2009). Toda vojskovanje in cilji, ki so določeni za vojaški instrument, so del realnosti zunanje politike in politične volje, zato je poučevanje strategije zahtevno.

Pri oblikovanju kurikuluma za izobraževanja o strategiji je treba odgovoriti na nekaj temeljnih vprašanj:

Kaj bi se lahko zahtevalo od stratega?

Za kaj izobražujemo bodočega stratega?

Kaj pomeni biti strateg?

Colin Gray meni, da bi lahko od bodočih strategov pričakovali:

- da znajo teoretizirati o abstraktnih pojmih in prispevati $\mathrm{k}$ razlagi univerzalne teorije strategije,

- da lahko ustvarijo zamisli in velike ideje, ki bodo predstavljale temeljno vodilo načrtovalcem v določenem zgodovinskem kontekstu,

- da lahko pripravijo operativni načrt ali strategijo za konkretno situacijo, v kateri se predvideva uporaba vojaškega instrumenta,

- da opravljajo poveljevanje in kontrolo nad izvedbo takšnega načrta (Gray, 2009, str. 13).

Kotnik pravi, da morajo visoki častniki:

- biti sposobni analitičnega povezovanja, ki jim bo omogočilo razumevanje celovitega strateškega okolja,

- obvladovati širok spekter dogajanj, ki bistveno presega dogajanja klasičnega bojišča,

- biti sposobni delovati v različnih okoljih, $\mathrm{v}$ katerih se bodo srečevali z različnimi rasami, religijami, kulturami itn. (Kotnik, 2008, str. 83). 
Strategi morajo biti sposobni usmerjati, voditi in oblikovati vojaške operacije, ki so namenjene temu, da se zavaruje prednost, ki je bila dosežena na vojaškem področju.

Troha pravi, da se »strateški vodja osredinja na oblikovanje vizije in strukture organizacije ter razporeja vire in sredstva. Deluje v nejasnih okoliščinah, ukvarja se z zapletenimi in zahtevnimi problemi, ki so pod vplivom dogodkov in organizacij, ki niso del vojske« (Troha, 2009, str. 77). Prav tako pa morajo biti strategi sposobni oblikovati in usmerjati vojaške aktivnosti, s katerimi podpirajo doseganje političnih ciljev; »vojaški poveljniki morajo biti sposobni opravljati večplastno in zapleteno vlogo vojaka znanstvenika in vojaka diplomata« (Kotnik, 2008, str. 82).

\section{Za kaj je treba izobraziti stratege?}

Gray opozarja, da mora poučevanje strategije upoštevati različne vloge, ki jih strategi lahko opravljajo, ter dejstvo, da je strategija znanstvena veda, ki je učitelji (predavatelji) ne smejo obravnavati kot skupek resnic, ki se ne spreminja.

Gray je prepričan, da mora izobraževanje v strategiji vplivati na posameznika in njegovo vedenje in ravnanje; strateg mora biti dinamičen produkt oziroma mešanica biologije, psihologije oziroma značaja, izkušenj in priložnosti. Samo inteligenca ne zadostuje za najvišjo kakovost v strateškem ravnanju. Dobri taktiki niso vedno tudi dobri strategi in dobri strategi ne potrebujejo zares bleščeče kariere iz taktične ravni bojevanja. Toda v praksi velja, da posameznik, ki bi lahko postal veliki strateg, ne bo nikoli dobil priložnosti na strateški ravni, če ne bo dobro opravljal dolžnosti na nižjih položajih, tudi če ne ustrezajo njegovim sposobnostim.

Do vojaškega voditelja na strateški ravni vodijo tri med seboj tesno povezane razvojne poti: selekcija, ki omogoča izbor posameznika, ki ima najbolj primerne osebnostne lastnosti in osebne vrednote; oblikovanje organizacijske kulture, ki omogoča spremljanje, vrednotenje in nagrajevanje posameznikov z napredovanjem na bolj odgovorne dolžnosti ter izobraževanje in usposabljanje, s katerim razvijamo znanje (torej izkušnje in spoznanje) in vedenje, ki ju posameznik potrebuje na najvišjih voditeljskih dolžnostih (Troha, 2009, str. 77).

Teorija strategije pomeni konceptualno podlago in razumevanje vojne. Je orodje, ki ga lahko uporabimo za analiziranje problemov vojne in miru. Razumevanje teorije pomeni, da ima študent koncept in vprašanja, ki mu pomagajo in ga vodijo skozi nadaljnji študij. Študij strateške teorije nam omogoča, da lahko razmišljamo strateško (Mahnken, 2010, str. 68).

Splošna teorija strategije je vedno pomembna. Različen je kontekst, v katerem se strategija uporablja, pri čemer lahko pride do velikih razlik v vsebini. Izziv je predvsem v opredelitvi potrebnih vsebin za bodoče stratege glede na zgodovino in kontekst. Lažje je doseči soglasje o tem, kaj je vsebina splošne teorije strategije, težko pa je opredeliti, katere strategije so tiste, ki jih bomo uporabljali danes in v prihodnosti. 
Gray trdi, da ne moremo napovedovati, kakšni konflikti bodo zahtevali profesionalne sposobnosti bodočih strategov, zato jih je treba pripraviti na različne možnosti, s katerimi bi se spoprijemali tako v miru kot v vojni. Treba pa je vključiti tudi klasično obliko vojskovanja. Gray je zagovornik obujanja pozabljenih veščin. Prepričan je, da danes le mislimo, da razumemo konflikte novega stoletja, in da je nevarno, če predvidevamo, da so današnji konflikti tisti, s katerimi se bomo srečevali v prihodnosti. Zato pravi, da bi moralo sodobno učenje strategije upoštevati različne konflikte in vse vidike konfliktov, čeprav to morda ni sodobna usmeritev in najbolj zaželeno.

\section{Kako dober je general, ki še ni poveljeval v boju? Kako sposobne in zmogljive bodo oborožene sile leta 2025 ali 2030 ?}

Težava pri poučevanju strategov je dvojna. Vojaški poklic se lahko znajde v položaju, v kateri mu že leta primanjkuje pravih bojnih izkušenj. Dodatno je strateška funkcija v vojski zahtevnejša od drugih poklicev, saj gre za vprašanja nacionalne varnosti in človekovega preživetja. Strateško izobraževanje mora biti zato čim bolj realistično.

Kotnik pravi, da »vojna od (vojaških) voditeljev še vedno zahteva tako znanost kot veščino《 in da »kreativnost, intuitivnost, vodenje, motiviranost in sprejemanje pravilnih odločitev«, ki so vse atributi veščin oziroma usposobljenosti in lastnosti posameznika, ostajajo ključni dejavnik tudi v okoliščinah sodobnega bojišča (Kotnik, 2008, str. 86).

Ustrezno strateško ravnanje v miru mora biti prilagodljivo, prožno in primerno, in mora omogočati delovanje $\mathrm{v}$ različnih oblikah konfliktov in vojskovanja. V prihodnosti bomo potrebovali vojaški instrument, ki bo v tem smislu sposoben podpreti politične odločitve. Zato mora strateško izobraževanje upoštevati zgodovinske izkušnje, ne sme pa biti vodeno ali se zanašati na preučevanje le sodobne zgodovine in trenutnih dogodkov.

\section{Kaj poučevati?}

Cilj izobraževalnega programa je, da strateg dobi dobro znanje in ustrezne kompetence, ne pa da le stremi za vrhunskimi rezultati. Najpomembnejše je, da stratega naučimo strateško presojati.

Gray ponuja sedem področij, na katerih naj bi strategi pridobili ustrezno znanje.

1. Razmišljati strateško; osredotočiti se na aktivnosti, ki omogočajo spoprijemanje s posledicami oziroma rezultati odločitev in predvideti takojšnje (neposredne) in nadaljnje učinke delovanja. Razložiti oziroma upravičiti zastavljeno končno stanje, način, s katerim bo to stanje doseženo, in sredstva, ki bodo pri tem uporabljena. 
2. Formalna izobrazba iz strategije je nujna. Ker vojna spreminja samo svoj značaj, ne pa tudi narave, je treba splošno teorijo strategije prenesti na vse zgodovinske primere vojne in konfliktov.

3. Implicirati teorijo $\mathrm{v}$ sodobne primere konfliktov in vojn ter presoditi vrednost teoretičnih izhodišč.

4. Razumeti nasprotnika in se biti sposoben prilagoditi novim sovražnikom.

5. Uporabljati zdrav skepticizem, kritično in kreativno razmišljanje in razumeti, da sta strateška prednost.

6. Razumeti, da lahko strategija kljub skepticizmu in nekaterim negativnim zgodovinskim izkušnjam deluje dovolj dobro, da se določene naloge izvedejo.

7. Poznati humanistične študije. Uspešno strateško delovanje je odvisno od ustrezne izobrazbe in razgledanosti posameznika. Strateg mora profesionalnim politikom in civilnim funkcionarjem znati razložiti aktualne in prihodnje vojaške aktivnosti, da jih bodo ti razumeli (Gray, 2009, str. 37-51).

Kotnik meni, da bodo poveljniki v prihodnosti morali obvladati bojne veščine, diplomatske spretnosti ter biti sposobni ocenjevati aktivnosti »ne le z vidika vojaške učinkovitosti, temveč tudi v luči vpliva političnih, etničnih, lingvističnih in verskih okoliščin, v okviru katerih delujejo« (Kotnik, 2008, str. 78).

Strateško ravnanje mora torej vsebovati sposobnost odločanja, poveljevanja in vodenja ter sposobnost razumevanja dogodkov. Zato je treba razumeti, kje so praktične omejitve formalnega izobraževanja v strategiji.

Poleg tega, da določimo, kaj je treba poučevati, je treba določiti, kdo naj bodo študenti strategije, kaj morajo doseči oziroma delati, kaj jih je treba poučevati in česa ne.

\section{DOSEDANJE IZKUŠNJE PRI IZOBRAŽEVANJU VOJAŠKIH STRATEGOV V SLOVENIJI KOT VODILO ZA OBLIKOVANJE IZOBRAŽEVANJA ZA BODOČE STRATEGE}

Oblikovanje kurikuluma vojaške strategije se je v Sloveniji začelo pred šestimi leti. V tistem času je bilo v Sloveniji že nekaj vojaških in civilnih strokovnjakov, ki so končali strateška izobraževanja na Nacionalni obrambni univerzi in nekaterih vojaških kolidžih v ZDA, na Kraljevi obrambni akademiji v Veliki Britaniji in generalštabnem tečaju v Nemčiji. Pri oblikovanju kurikuluma je bilo precej težav, saj je bilo ljudi, ki bi imeli izkušnje na strateški ravni in hkrati solidno teoretično znanje, zelo malo. Pri oblikovanju kurikuluma je pomagala Fakulteta za družbene vede z ekspertizo, ki pa je bila predvsem teoretična.

V nadaljevanju članka so predstavljeni izkušnje in predlogi avtorjev, ki izhajajo iz neposredne udeležbe enega avtorja pri predmetu vojaška strategija na generalštabnem 
programu v SV in izkušenj obeh avtorjev, ki izhajajo iz opravljanja funkcij na strateški ravni ter teoretičnega znanja, ki sta ga pridobila na strateških izobraževanjih.

\section{Učitelji strategije}

V procesu oblikovanja kurikuluma vojaške strategije smo v Sloveniji pridobili nekaj izkušenj, ki podpirajo teoretična izhodišča pri oblikovanju študija strategije.

Prva pomembna slovenska izkušnja je prinesla spoznanje, da je že na ravni majorja ali podpolkovnika treba prepoznati posameznike, ki bodo poučevali strategijo. Zagotoviti je treba njihov načrtni strokovni in karierni razvoj. Opraviti morajo ustrezna vojaška in civilna podiplomska izobraževanja, sodelovati v procesu vojaškega izobraževanja in usposabljanja (VIU) kot inštruktorji oziroma asistenti pri predmetu strategija ter pridobiti praktične izkušnje iz dela na strateški ravni vodenja in poveljevanja, nato pa se s teoretičnim znanjem in praktičnimi izkušnjami vrniti v proces izobraževanja kot učitelji strategije. Ključni dejavniki, brez katerih ni mogoče oblikovati in organizirati nacionalnega vojaškega visokošolskega sistema, so kakovostni predavateljski kadri (Žabkar, Svete, 2008; SPOR09). ${ }^{2}$

Pri oblikovanju ustreznih nacionalnovarnostnih strategij bo v prihodnje vedno pomembnejše učinkovito sodelovanje med civilnimi in vojaškimi akterji. Tudi pri poučevanju strategije je zato pomembna izkušnja, da lahko dosežemo boljše izobraževalne rezultate le, če bodo v poučevanje strategije kot stalni štab (sodelavci) vključeni vojaški in civilni strokovnjaki, teoretiki in praktiki z delovnimi izkušnjami s civilnega in vojaškega področja, na strateški nacionalni in mednarodni ravni.

Naslednji izziv, ki ga je treba rešiti, je cilj izobraževanja, vprašanje torej: kaj je izhodni rezultat? Študenti strategije morajo razviti sposobnost razumevanja in kritičnega razmišljanja o spretnosti in znanju oblikovanja in uporabe nacionalne vojaške moči, s katero se lahko podprejo nacionalni interesi. Razviti morajo sposobnost kritičnega razmišljanja in uporabe konceptov ter razumeti sodobne in prihodnje strateške izzive.

Kurikulum vojaške strategije je do zdaj vseboval teme o teoriji vojne in vojaške sile, vojaško strategijo, vojno strategijo, strateško načrtovanje, načrtovanje strateških resursov, strateško načrtovanje za prihodnost ter pripravo lastne (nacionalne) vojaške

\footnotetext{
Ključne ugotovitve s področja kadrovske zagotovitve procesa vojaškega izobraževanja in usposabljanja v Slovenski vojski v okviru strateškega pregleda obrambnega resorja, ki je bil opravljen leta 2009, so bile: da kadrovski načrt ne predvideva strokovnega kadra za popolnjevanje dolžnosti v sistemu VIU: niti izvajalcev VIU niti tistih, ki zagotavljajo nemoteno izvedbo procesov VIU; obvezne usmeritve za sistem kariernih poti pripadnikov stalne sestave SV tudi danes ne določajo, da je treba zagotoviti načrten razvoj kadrov za popolnjevanje dolžnosti $v$ sistemu VIU; večina izvajalcev VIU, ki delajo v centrih, ki zagotavljajo učiteljski kader, in v vojaških šolah, se udeleži dodatnega pedagoško-andragoškega usposabljanja, vendar šele potem, ko so postavljeni na dolžnost; $v$ šole in centre se razporejajo tudi kadri, ki nimajo potrebnega znanja in predhodnih izkušenj za kakovostno delo v izobraževanju in usposabljanju ter dela v izobraževalnem ali razvojnem procesu ne razumejo kot poklicni in strokovni izziv; ne usposabljamo vojaških strokovnjakov, ki bi lahko suvereno in kakovostno prevzeli izvedbo temeljnih vojaških predmetnih področij VIU v SV; poseben problem so strokovnjaki, ki bi prevzeli izvedbo temeljnih vojaških predmetnih področij na najvišjih oblikah VIU.
} 
strategije. Izvedba vseh zahtevnih tem je bila praktično nemogoča in zastavljene cilje je bilo težko v celoti izpolniti, saj so bili vsebinsko preobsežni in prezahtevni. Iz teh ugotovitev izhaja naslednja izkušnja: postaviti dosegljive cilje ter jih podpreti $\mathrm{s}$ temami in vajami, ki jih je mogoče izvesti z danimi kadrovskimi in tehničnimi zmgljivostmi. Zelo težko je zmanjšati raven ambicij in pričakovanj, vendar se je pri določanju ciljev in tematskega obsega izobraževanja treba ravnati po načelu: manj je več ter ohraniti kredibilnost programa. Izogniti se je treba ustaljenemu ravnanju, ko izvedba postane formalnost, ne zagotavlja pa pričakovane kakovosti.

Pri oblikovanju kurikuluma strategije se je treba odločiti tudi, kakšne vrste strategov potrebujemo. Izkušnje kažejo, da so v izobraževalnem procesu zelo redko posamezniki, ki združujejo sposobnost delovanja na različnih strateških področjih delovanja, kot so strateško vodenje, načrtovanje, razvoj konceptov ipd. Zato je treba kurikulum oblikovati tako, da je mogoče pri udeležencih okrepiti njihove naravne sposobnosti ter tako zagotoviti boljše izobraževalne rezultate.

\section{Časovni obseg programa predmeta strategija}

Pridobljena je bila še ena pomembna izkušnja: pri doseganju cilja izobraževanja je pomemben tudi čas. Pomembni so tudi izbor študentov, priprava študijskega procesa v metodološkem smislu (metode in tehnike poučevanja), izbor študijskega materiala, primerjava kurikuluma z drugimi programi, tečaji (nadgradnja, povezava, prenos izkušenj) ipd.

Čas, ki je na voljo za izvedbo predmeta, je odločilen dejavnik pri doseganju ciljev kurikuluma. Za izvedbo predmeta vojaška strategija je predvidenih 48 ur za predavanja ter praktično vajo. ${ }^{3} \mathrm{~V}$ praksi je čas, ki je bil na razpolago, prekratek za kakovostno izvedbo tem, zato se je moral predavatelj sam odločati o tem, kaj bo iz programa izločil. Še težja je bila izvedba predmeta v takem časovnem obsegu v generaciji, ki se je izobraževala ob delu, in se je procesa izobraževanja udeleževala en teden na mesec, pri čemer je bil obseg predavanj najmanj osem ur na dan, sledil pa je še individualni študij. Pri oblikovanju predmetov je zato pomembno, da lahko predavatelj svobodno presoja o načinu izvedbe tem. Kadar je čas omejen, se je pomembneje posvetiti ključnim temam, kot pa le predelati predpisano snov.

\section{Vloga učiteljev pri izbiri tem ali fleksibilnost predmetnika}

Možnost za fleksibilno obranavo znotraj predpisanih tem je pomembna, ker lahko v izvedbo predmetov vključimo razprave in izkušnje o aktualnih svetovnih ali regionalnih dogodkih. Predavatelj mora imeti znanje in sposobnosti, da dogodke iz življenja vključi v svoje predavanje, da spodbudi razpravo in prenos teoretičnega znanja udeležencev na aktualne dogodke. To udeležencem izobraževanja daje možnost izobraževanja s področja vojaške strategije za oblikovanje njihovih lastnih

\footnotetext{
Ko je Krek leta 2006 prevzel predmet vojaška strategija, je ta obsegal 48 ur; prav toliko ur je predmetnik generalštabnega programa obsegal leta 2008, ko sta ga Žabkar in Svete kritično primerjala s primerljivimi programi v tujini (Žabkar, Svete, 2008, str. 202-203), program pa velja še danes (Program, 2007).
} 
strategij, ki bi bile uporabne v konkretnem, resničnem dogodku. Študenti strategije so lahko odlično strokovno občinstvo za kritično presojanje in dopolnjevanje aktualnih strateških dokumentov na področju obrambnega načrtovanja, predpisov in doktrinarnih dokumentov. Izkušnja iz prakse, ki jo je treba upoštevati pri oblikovanju kurikuluma strategije, kaže, da mora biti predmetnik dovolj fleksibilen, da lahko predavatelj vključi v razpravo in podkrepitev teorije aktualne dogodke. Tako poskrbi za kakovostnejšo izvedbo in uporabi mnenja udeležencev za pripravo strokovnih presoj aktualnih normativnih in strokovnih dokumentov s področja nacionalne varnosti.

\section{Študijska literatura in gradivo}

Za kakovosten študij je pomembno, kakšen študijski material se uporablja pri izvedbi izobraževanja strategije. Trenutno je na razpolago veliko uporabne literature v angleščini, nekaj je je tudi v nemščini, fancoščini, italijanščini in celo ruščini. Pri uporabi teh gradiv je seveda omejitev jezikovno znanje predavateljev in udeležencev izobraževanja. V angleščini se je jezikovno znanje v preteklih letih bistveno izboljšalo, znanje drugih jezikov pa je v manjšini. Toda največjo težavo še vedno pomeni vprašanje, kako med veliko količino razpoložljivega študijskega gradiva izbrati pravega. Razmeroma lahko je izbrati gradivo o teoriji strategije, prepoznavanju uporabe strategije v zgodovini vojskovanja in strategije v nekaterih sodobnih konfliktih. Večja težava je pri izboru študijske literature, primerne za preučevanje strategije in vojaške strategije druge svetovne vojne v Sloveniji, osamosvojitvene vojne v Sloveniji ter vojn na Balkanu po letu 1991, torej strategij, ki spadajo v okvir posebnega slovenskega nacionalnovarnostnega interesa. Gradiva in knjig, ki obravnavajo naštete dogodke, je dovolj, vendar je treba izločiti strokovno utemeljene dele, ki bi bili ustrezno študijsko gradivo. Zato je predavatelj največkrat postavljen ne le v vlogo pripravljalca študijskega gradiva, temveč tudi v vlogo pisca gradiv. Predavatelj strategije mora torej pisati tudi kakovostna študijska gradiva, ki obravnavajo strateška vprašanja.

\section{Povezanost predmeta strategija z drugimi področji v programih vojaškega izobraževanja}

Izkušnja, pridobljena med vojaškim izobraževanjem, je pokazala tudi, da je povezavaz drugimi predmeti in drugimi tečaji oziroma programi izobraževanja zelo pomembna. Pomembna sta tako ustrezna nadgradnja znanja kot prepletanje nekaterih vsebin med posameznimi predmeti znotraj enega tečaja in med njimi. Poseben izziv je, kako preprečiti podvajanje in kako zagotoviti, da bi bile nekatere pomembne teme vključene vsaj v en tečaj. Pri pripravah kurikulumov različnih izobraževalnih programov lahko tako povezavo zagotovi le ustrezno strokovno usklajevanje, ki mora biti zagotovljeno tudi med potekom izvajanja programov oziroma predmetov.

\section{Udeleženci izobraževanja in njihovo predznanje}

Za oblikovanje študijskega programa s področja strategije je nujno upoštevati tudi udeležence izobraževanja. V proces izobraževanja prihajajo z različnimi izkušnjami, 
nekateri so končali predhodna izobraževanja $\mathrm{v}$ tujini, imajo različno civilno in vojaško predznanje, različno znanje tujih jezikov in različno sposobnost priprave pisnih izdelkov na podiplomski ravni izobraževanja. V svetu se v nekatere programe strateškega izobraževanja vključujejo skupaj civilne in vojaške osebe različnih narodnosti (civilisti in vojaki). Zelo težko je poiskati skupno izhodišče, na katerem bi temeljilo kakovostno poučevanje predmeta, če predavatelji nimajo vpliva na zahteve kurikuluma in ne poznajo sposobnosti študentov.

Kakovost predavanj in študija je mogoče povečati z nekaterimi dejavnostmi, ki olajšajo prilagoditev načina dela udeležencem izobraževanja. To so:

- intervju z udeležencem izobraževanja, ki se bo vključil v program izobraževanja, pred izbiro udeleženca ali takoj po njej;

- vnaprej pripravljeno izbrano gradivo, ki se lahko pripravi za vsakega posameznika in/ali za vse udeležence izobraževanja, posebno, če je skupina udeležencev velika;

- izvedba pripravljalnega tečaja, s katerim se vnaprej določi raven znanja. Na podlagi tega se posamezniki lahko pozneje nemoteno vključijo v izobraževalni proces. To se upošteva, če predavatelj lahko vnaprej določi posameznikovo izkušenost in znanje.

Vse naštete aktivnosti se lahko izvedejo v praksi, čeprav je težko najti učinkovit način za izvedbo. Lažje izvedljiv je način, ko znanje, ki ga posamezniki potrebujejo za uspešno vključitev v strateško izobraževanje, študenti pridobijo na predhodnem obveznem tečaju (operativna raven). V slovenskem primeru to pomeni, da bi v predmetnik višjega štabnega tečaja vključili predmet, ki bi udeležencem zagotovil osnovno znanje o strategiji (t. i. Strategija 101).

\section{Spremljanje uspešnosti absolventov po končanem programu študija strategije}

Za nadaljnje izobraževanje o strategiji v Sloveniji sta pomembni še dve izkušnji. Delo tistih, ki so končali izobraževanje, je treba spremljati še naprej, predvsem takrat, ko prevzamejo dolžnosti na strateški ravni odločanja. Spremljanje in ocenjevanje rezultatov dela tudi v tem obdobju lahko izboljša njihovo pripravljenost in sposobnost za opravljanje strateških funkcij. Velikokrat se namreč dogaja, da posamezniki razumejo delovanje nacionalnega varnostnega sistema, področje dela in odgovornosti na posameznih funkcijah/dolžnostih na strateški ravni, vse do takrat, ko se morajo srečati z resničnim dogajanjem, z vplivom nacionalne politike in civilne družbe na delovanje sistema in posameznikov. Poseben problem na tej ravni je nesposobnost posameznikov jasno, nedvoumno in razumljivo predstaviti strateške probleme. Celo visoki častniki na strateških položajih, tudi taki, ki so opravili izobraževanje na strateški ravni, ne znajo razumljivo pojasniti strokovnih argumentov civilnim funkcionarjem in politikom. Po drugi strani pa civilni funkcionarji in politiki niso ustrezno izobraženi o nacionalni varnosti, kar prav tako otežuje medsebojno komunikacijo in presojanje o pomembnih stvareh, ki so velikokrat nacionalnega pomena. V Sloveniji se je ta problem kazal predvsem pri obravnavi vprašanj o 
posledicah zmanjševanja obrambnega proračuna, pri obravnavi nekaterih pomembnejših programov nakupov vojaške opreme, pri razpravah o sodelovanju Slovenske vojske v Afganistanu in nazadnje pri razpravi o ukinitvi Slovenske vojske. Zaradi delovanja v okolju, v katerem je razpoložljivih (finančnih in materialnih) virov vse manj, so politične veščine visokih častnikov, ki zagotavljajo prepričljivo in argumentirano izražanje potreb vojske, vedno pomembnejše (Kotnik, 2008, str. 82-83).

Študenti strategije se morajo usposobiti za spoprijemanje z izzivi, ki jih čakajo na strateških dolžnostih. Znati morajo konstruktivno razpravljati ter ustrezno argumentirati strokovna vojaška stališča civilistom in politikom. Že med študijem naj bi se $\mathrm{v}$ proces izobraževanja vključevali predstavniki vladnih in nevladnih organizacij in civilne družbe. Študente strategije je treba seznaniti z različnimi okoliščinami in jim postavljati zahtevna vprašanja o reševanju aktualnih kritičnih razmer. Izobraževanje na tej ravni je njihovo zadnje sistemsko izobraževanje oziroma zadnje akademsko izobraževanje, pri čemer lahko svobodno izražajo in zagovarjajo svoja stališča in mnenje ter kritizirajo, ne da bi to negativno vplivalo na obrambni ali nacionalnovarnostni sistem.

Sklep V okviru foruma srednjeevropskih držav na področju vojaškega izobraževanja se pravkar oblikuje kurikulum strateškega izobraževanja. Pobuda je nastala iz potreb predvsem manjših držav, ki so se jim pridružile tudi večje države. Skupni kurikulum za izobraževanje vojakov in civilistov na strateški ravni bi državam olajšal oblikovanje kurikuluma. Poenotil bi strokovno znanje na strateški ravni, kar bi pripomoglo k boljšemu sodelovanju med agencijami ne le v državah, temveč tudi na mednarodni ravni (Coprehensive Approach), predvsem pri odločanju in izvajanju dejavnosti, ki so povezane s svetovnimi krizami. Predvidena je izmenjava predavateljev, predvsem za predmete, katerih izvajalce je težko zagotoviti znotraj nacionalnega okvira. To bi izboljšalo kakovost izvedbe in pripomoglo k boljšemu znanju angleškega jezika, saj bi predmet potekal v angleškem jeziku. Tudi sicer se načrtovalci tega kurikuluma nagibajo k izvajanju predavanj v angleškem jeziku za vse udeležence. Enoten učni jezik bi omogočil, da bi lahko država poslala svoje študente študirat v tujino, doma pa bi poslušali samo tiste predmete, ki so izključno v nacionalni domeni, kot so vaje za izboljšanje delovanja sistema nacionalne obrambe ali njenega dela in druge podobne vsebine.

V Sloveniji se moramo še naprej dejavno vključevati v oblikovanje skupnega kurikuluma strategije in v njegovo konkretno izvedbo ter podpirati pobude, ki bodo študij olajšale in pripomogle k njegovi kakovosti. Majhna vojska, kot je slovenska, bo morala v prihodnje še bolje izkoristiti različne možnosti za kakovostno strokovno izpopolnjevanje kadrov in boljše rezultate glede na vložena sredstva in čas. Pomembno pa je, da smo pri takih pobudah dejavni, saj imamo izkušnje in znanje, ki se nam jih ni treba sramovati. 
Pri svojih prizadevanjih za kakovostne učitelje, študente in programe za študij strategije potrebujemo tudi podporo politike. Nedvomno bi bil zelo primeren in pomemben tečaj, ki bi bil oblikovan zato, da se s sistemom nacionalne varnosti in predvsem $\mathrm{s}$ stvarmi, ki obravnavajo obrambni sistem, seznanijo tudi člani parlamenta in člani vlade ter drugi pomembni politični funkcionarji, ki bi tako izboljšali splošno znanje, se seznanili s terminologijo na obrambnem področju in z znanjem, ki je nujno za delovanje in predvsem odločanje na strateški ravni.

1. Gray, Colin S., 2009: Schools for Strategy: teaching Strategy for $21^{\text {st }}$ Century Conflict, http:/www.StrategicStudiesInstitute.army.mil, 5. 1. 2012

2. Hughes, Wayne P. jr, 1989: The Strategy - Tactics relationship. V Colin S. Gray and Roger W. Barnett, ur. Seapower and Strategy. Annapolis, MD, Naval institute Press, 1989, 3. poglavje.

3. Lyman, Robert, 2008: The Generals: From defeat to Victory, Leadership in Asia, 19411945. London, UK, Constable.

4. Kotnik, Igor, 2008. Kakšen naj bo sodobni častnik Slovenske vojske in kako do njega. Bilten Slovenske vojske. 2008-10/št. 1.

5. Allen, Charles D. 2010. Redress of Proffesional Military Education, The Clarion Call. Joint Forces Quarterly, 59, 4th Q 2010.

6. Bethel Scott A., Aaron Prupas, Tomislav Z. Ruby, Michael V. Smith. 2010. Change Culture, Reverse Careerism. Joint Forces Quarterly, 58, 3rd Q 2010.

7. Mahnken G. Thomas, 2010. Strategic Theory. V Baylis J., Wirtz James J., Gray S. Colin, ur. Strategy in the Contemporary World, Oxford, str. 67-81.

8. McCausland, Jeffrey D. 2008. Developing Leaders for 21.st Century. Strategic Studies Institute, USA.

9. Program generalštabnega šolanja, 2007. MORS, št. 603-63/2007-2, z dne 19. 4. 2007.

10. Salmoni Baraka A., Hart J., McPherson R., Winn Aidan K.. 2010. Growing Strategic Leaders for Future Conflict. Parameters. Spring 2010.

11. Strateški pregled obrambnega resorja 2009, javno objavljena verzija, http://www.mo.gov. si/fileadmin/mo.gov.si/pageuploads/pdf/ministrstvo/SPOR2009.pdf, 15. 2. 2012.

12. Troha N. 2009. Usposabljanje voditeljskih veščin: modna muha ali potreba-Pomen vadišča za usposabljanje voditeljskih veščin pri razvoju voditeljev. Bilten Slovenske vojske. $2009-11 /$ st. 4.

13. Žabkar, A., Svete, U., 2008. Šolanje vojaških profesionalcev med tradicionalnimi izhodišči in (post) modernimi izzivi. Bilten Slovenske vojske. 2008-10/št. 1. 